\title{
The Electrochemical Behavior of Carbon Steel Wires of Nepal in Different Environments
}

\author{
Jagadeesh Bhattarai* \\ Central Department of Chemistry, Tribhuvan University, GPO Box 2040, Kathmandu, Nepal. \\ e-mail:bhattarai_05@yahoo.com.
}

\begin{abstract}
The electrochemical behavior of carbon steel wires of Nepal is studied in $1 \mathrm{M} \mathrm{HCl}, 0.5$ $\mathrm{M} \mathrm{NaCl}$ and $1 \mathrm{M} \mathrm{NaOH}$ solutions at $25^{\circ} \mathrm{C}$, open to air using immersion tests and electrochemical measurements. The corrosion rates of the carbon steel wires were found to be about 20-50 mm/y in acidic $1 \mathrm{M} \mathrm{HCl}$ and $0.1-0.2 \mathrm{~mm} / \mathrm{y}$ in neutral $0.5 \mathrm{M} \mathrm{NaCl}$. The corrosion rate of all the examined steel wires in alkaline $1 \mathrm{M} \mathrm{NaOH}$ solution (that is, 7 - 18 $\times 10^{-3} \mathrm{~mm} / \mathrm{y}$ ) was found nearly three orders of magnitude lower corrosion resistance than in $1 \mathrm{M} \mathrm{HCl}$ solution at $25^{\circ} \mathrm{C}$, mostly due to an ennoblement of the open circuit potentials of the steel wires at passive potential regions (that is, -200 to $250 \mathrm{mV}$ vs SCE) in $1 \mathrm{M} \mathrm{NaOH}$ solution. The steel wires seem to be very corrosion resistance materials in very alkaline environments like cement-based materials.
\end{abstract}

Keywords: Carbon steel wire, corrosion tests, polarization measurement, $\mathrm{HCl}, \mathrm{NaCl}$ and $\mathrm{NaOH}$ solutions

\section{Introduction}

Various types of steels have been used as structural materials since the beginning of $20^{\text {th }}$ century and it is becoming one of the major construction materials of the world. ${ }^{1}$ Over the years, large numbers of steels are used in commercial buildings, marine structures, bridges etc. However, destruction of steels by environmental factors is becoming one of the main problems for the industrial companies in the world. If the on-going environmental corrosion damages on steels surface are not addressed, section loss of these structures will occur and a significant repair or replacement may eventually be required. Therefore, as time goes on we will be faced new corrosion problems of the steel-structures in different environments.

In this context, corrosionists are recently focused to find out better quality models for the progression of steel corrosion with time. Good control of corrosion of steels requires the awareness and co-operation of the entire design team including engineers and corrosionists. In order to ensure the more durability of the new steel-structures, we need to understand what can be done to ensure that the corrosion risk of the steels should be reduced to a

${ }^{*}$ Corresponding author 
minimum in different environments. In general, the most harmful factors for steels corrosion damage are oxidizing acids and chloride ion, and the most beneficial is very alkaline environments. Steels passivated generally at a $\mathrm{pH}$ higher than 10 , eventhough the passivity decreases in very strong alkaline solutions at high temperature in which steel has a tendency to dissolve as ferrous ions $\left(\mathrm{HFeO}_{2}{ }^{-}\right){ }^{1}$ Therefore, many alkaline environments have been employed in many chemical processing industries where steel equipments are used. ${ }^{2}$

Many corrosion studies of steels had performed by using the surface analysis techniques. ${ }^{3-6}$ The corrosion behavior of steels has been mainly investigated in inorganic $\operatorname{acids}^{7,8}$ a strongly oxidizing peracetic acid ${ }^{9}$, non-oxidation organic acids ${ }^{10}$, salts ${ }^{11}$, alkaline solutions ${ }^{12,13}$ and marine media. ${ }^{14-17}$ It has been reported that the Prunus cerasus juice ${ }^{18}$ and quinolin-5-ylmethylene-3-\{[8-(trifluoromethyl)quinolin-4-yl]thio $\}$ propanohydrazide ${ }^{19}$ act as inhibitors for corrosion of carbon steels in hydrochloric acid solutions. Similarly, it has been studied the corrosion behavior of carbon steels in simulated rain water. ${ }^{20}$ The corrosion rates of different structural steels were strongly influenced by the climatic conditions prevailing at the exposure sites and the presence of $\mathrm{SO}_{2}$ as well as salinity in the environments had changed the structure and protective properties of rust formed on the steels' surface. ${ }^{21}$ But little has been studied about the corrosion behavior of steels produced in Nepal. ${ }^{22,23}$ In this context, the present work is aimed to study the corrosion behavior of three carbon steel wires of Nepal (which are used as construction materials for a reinforcing concrete) in acidic $1 \mathrm{M} \mathrm{HCl}$, neutral $0.5 \mathrm{M} \mathrm{NaCl}$ and alkaline $1 \mathrm{M} \mathrm{NaOH}$ solutions at $25^{\circ} \mathrm{C}$, open to air using immersion tests and electrochemical measurements.

\section{Experimental Methods}

Three different branded carbon steel wires (named as SW-4, SW-5 and SW-6) produced by different Steel and Iron Companies of Nepal were used to carry out the present research work. These carbon steel wires are the most commonly available in the local market in Kathmandu valley and are used for construction purposes.

Prior to the immersion tests and electrochemical measurements, the steel wire specimens were mechanically polished with a silicon carbide paper No. 600 to 1500 in cyclohexane, degreased by acetone and dried in air. The corrosion rate of the steel wire specimens was estimated from the weight loss after immersion for 240 hours in $100 \mathrm{~mL}$ of 1 $\mathrm{M} \mathrm{HCl}, 0.5 \mathrm{M} \mathrm{NaCl}$ and $1 \mathrm{M} \mathrm{NaOH}$ solutions at $25^{\circ} \mathrm{C}$, open to air. The weight loss measurement was done two times or more for each specimen and the average corrosion rate of individual steel specimens was estimated. The time dependence of the corrosion loss of the steel wires in different environments was also estimated at various time intervals.

The open circuit potential (OCP) of the carbon steel wire specimens was measured after immersion for 72 hours in acidic $1 \mathrm{M} \mathrm{HCl}$, neutral $0.5 \mathrm{M} \mathrm{NaCl}$ and alkaline $1 \mathrm{M} \mathrm{NaOH}$ solutions at $25^{\circ} \mathrm{C}$, open to air. The cathodic and anodic potentiostatic polarization measurements were also carried out on the steel wires in $1 \mathrm{M} \mathrm{NaOH}$ solution at $25^{\circ} \mathrm{C}$. A platinum mesh and saturated calomel electrode were used as counter and reference electrodes, respectively. The steel wire specimens were used as a working electrode. All the potentials given in this paper are relative to saturated calomel electrode (SCE). 


\section{Results and Discussion}

Figure 1 shows the corrosion rates of three steel wires produced by different Steel and Iron Companies of Nepal after immersion for 240 hours in acidic $1 \mathrm{M} \mathrm{HCl}$, neutral $0.5 \mathrm{M}$ $\mathrm{NaCl}$ and alkaline $1 \mathrm{M} \mathrm{NaOH}$ solutions at $25^{\circ} \mathrm{C}$, open to air. The corrosion rates of all three steel wires are in the ranges of about 2-5 $\times 10^{1}, 1-2 \times 10^{-1}$ and 7-18 $\times 10^{-3} \mathrm{~mm} / \mathrm{y}$ in $\mathrm{HCl}$, $\mathrm{NaCl}$ and $\mathrm{NaOH}$ solutions, respectively. Among three different steel wires of Nepal, samples SW-4 and SW-5 showed the corrosion rate in the range of about 2.0-2.5 $\times 10^{1} \mathrm{~mm} / \mathrm{y}$ in $1 \mathrm{M} \mathrm{HCl}$ solution which is nearly half of the corrosion rate of the SW-6 sample. The corrosion rate of the SW-6 is about $5.0 \times 10^{1} \mathrm{~mm} / \mathrm{y}$ in $1 \mathrm{M} \mathrm{HCl}$ solution. Similarly, the corrosion rates of both SW-4 and SW-5 are about 1.0-1.1 $\times 10^{-1} \mathrm{~mm} / \mathrm{y}$, while the corrosion rate of the SW-6 is two times higher than those of SW-4 and SW-5 (that is, about $2.0 \times 10^{-1}$ $\mathrm{mm} / \mathrm{y}$ ) in neutral $0.5 \mathrm{M} \mathrm{NaCl}$ solution at $25^{\circ} \mathrm{C}$. On the other hand, the steel wire samples SW-4 and SW-5 showed almost the same corrosion rates of about $7.0 \times 10^{-3} \mathrm{~mm} / \mathrm{y}$ in $1 \mathrm{M}$ $\mathrm{NaOH}$ solution. However, the corrosion rate of SW-6 is about two and half times higher (that is, $18 \times 10^{-3} \mathrm{~mm} / \mathrm{y}$ ) than those of SW-4 and SW-5 samples in $1 \mathrm{M} \mathrm{NaOH}$ solution. Consequently, all the examined carbon steel wires produced by different companies of Nepal showed very high corrosion resistance in alkaline $1 \mathrm{M} \mathrm{NaOH}$ than those in acidic $1 \mathrm{M}$ $\mathrm{HCl}$ and neutral $0.5 \mathrm{M} \mathrm{NaCl}$ solutions at $25^{\circ} \mathrm{C}$, open to air. Furthermore, both steel wires produced by Companies 4 (SW-4) and 5 (SW-5) showed slightly lower corrosion rates than that of the steel wire produced by company $6(\mathrm{SW}-6)$ in all acidic, neutral and alkaline solutions.

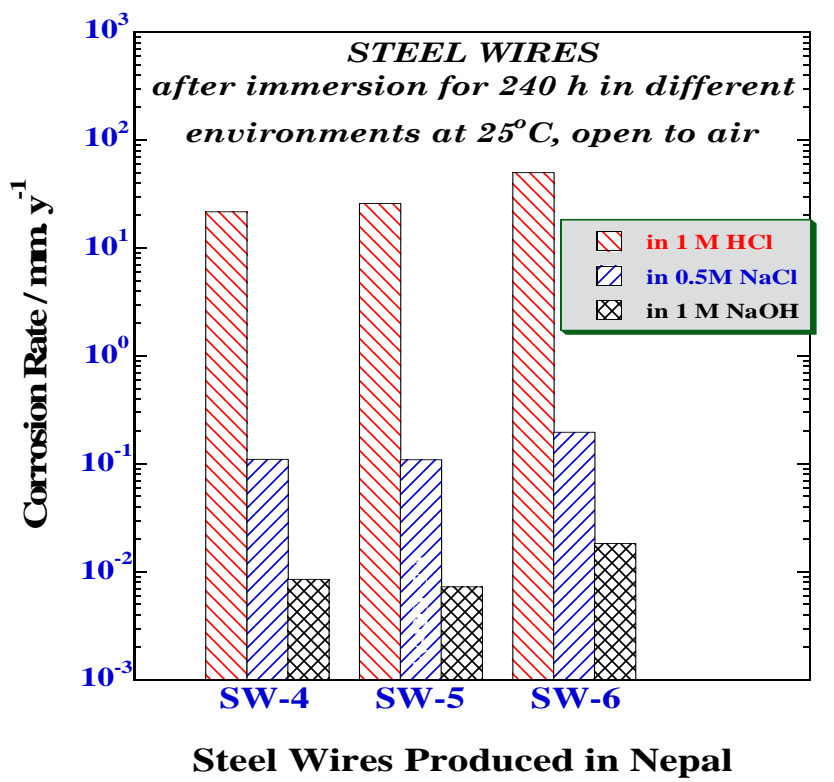

Figure 1: Corrosion rates of three different steel wires of Nepal after immersion for 240 hours in 1 $\mathrm{M} \mathrm{HCl}, 0.5 \mathrm{M} \mathrm{NaCl}$ and $1 \mathrm{M} \mathrm{NaOH}$ solutions at $25^{\circ} \mathrm{C}$, open to air. 
In order to clarify the time dependence of the corrosion rate of the carbon steel wires, the corrosion rate of the wire samples were estimated after immersion for various time intervals. Figures 2 (a), 2 (b) and 2 (c) show the changes in corrosion rates of the steel wires in acidic $1 \mathrm{M} \mathrm{HCl}$, neutral $0.5 \mathrm{M} \mathrm{NaCl}$ and alkaline $1 \mathrm{M} \mathrm{NaOH}$ solutions, respectively, at $25^{\circ} \mathrm{C}$ as a function of immersion time. The corrosion rates of the steel wires are generally high at initial period of immersion (that is, 2 hours) in all acidic, neutral and alkaline solutions. However, the corrosion rates of the carbon steel wires become almost steady after immersion for about 48 hours in $1 \mathrm{M} \mathrm{NaOH}$ (Fig. 2.c), while the corrosion rates of the steel wires in $1 \mathrm{M} \mathrm{HCl}$ (Fig. 2.a) and $0.5 \mathrm{M} \mathrm{NaCl}$ (Fig. 2.b) solutions become almost steady after immersion for about 120 hours. These results revealed that initially faster dissolution of the carbon steel wires produced in Nepal results in faster passivation by forming a more protective passive film on the surface of the steel wire in alkaline $1 \mathrm{M} \mathrm{NaOH}$ solution. Consequently, all the examined carbon steel wires showed significantly higher corrosion resistance in $1 \mathrm{M} \mathrm{NaOH}$ solution than those in $1 \mathrm{M} \mathrm{HCl}$ and $0.5 \mathrm{M} \mathrm{NaCl}$ solutions at $25^{\circ} \mathrm{C}$, open to air.
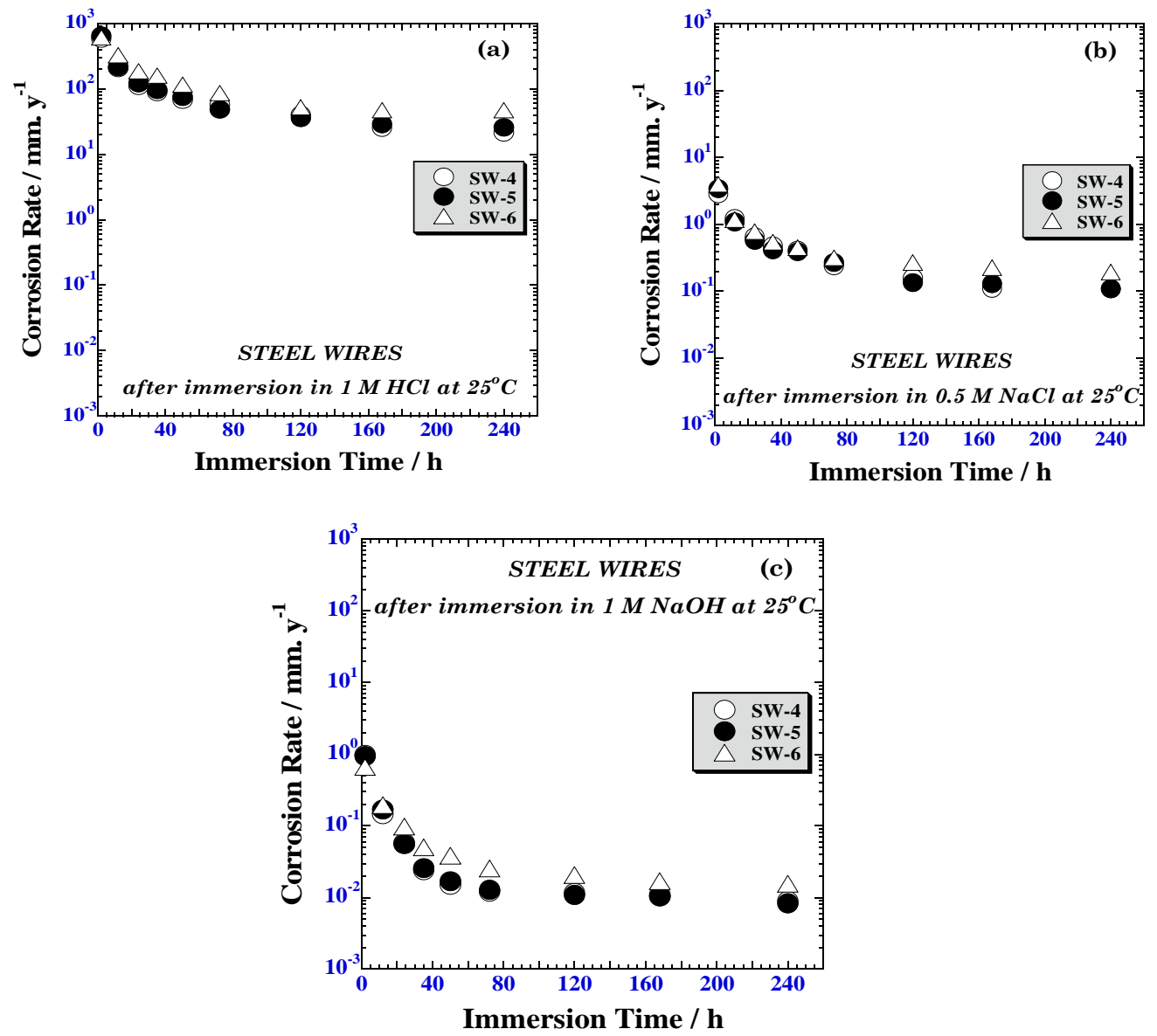

Figure 2: Changes in corrosion rates of the carbon steel wires of Nepal in (a) $1 \mathrm{M} \mathrm{HCl,} \mathrm{(b)} 0.5 \mathrm{M}$ $\mathrm{NaCl}$ and (c) $1 \mathrm{M} \mathrm{NaOH}$ solutions at $25^{\circ} \mathrm{C}$, as a function of immersion time. 
Electrochemical measurements were carried out for a better understanding of the corrosion behavior of the steel wires of Nepal after immersion for 72 hours in acidic $1 \mathrm{M}$ $\mathrm{HCl}$, neutral $0.5 \mathrm{M} \mathrm{NaCl}$ and alkaline $1 \mathrm{M} \mathrm{NaOH}$ solutions at $25^{\circ} \mathrm{C}$, open to air. Figures 3 (a), (b) and (c) shows the changes in open circuit potentials for the carbon steel wires in $1 \mathrm{M}$ $\mathrm{HCl}, 0.5 \mathrm{M} \mathrm{NaCl}$ and $1 \mathrm{M} \mathrm{NaOH}$ solutions, respectively, as a function of immersion time. Over all the changes in the open circuit potentials for all the examined wires are not significant with immersion time. The open circuit potential of all three samples is about $560 \mathrm{mV}$ (SCE) after immersion for 10 seconds and gradually shifts to positive direction with immersion time up to $2 \mathrm{~h}$. The OCPs of the carbon steel wires reach stationary values of about -460 to $-515 \mathrm{mV}$ (SCE) after immersion for $72 \mathrm{~h}$ in $1 \mathrm{M} \mathrm{HCl}$ (Fig. 3.a). On the other hand, the small changes in the OCPs of the steel wires are observed in neutral $0.5 \mathrm{M} \mathrm{NaCl}$ solution, although the OCPs shift negative direction with immersion time (Fig. 3.b).
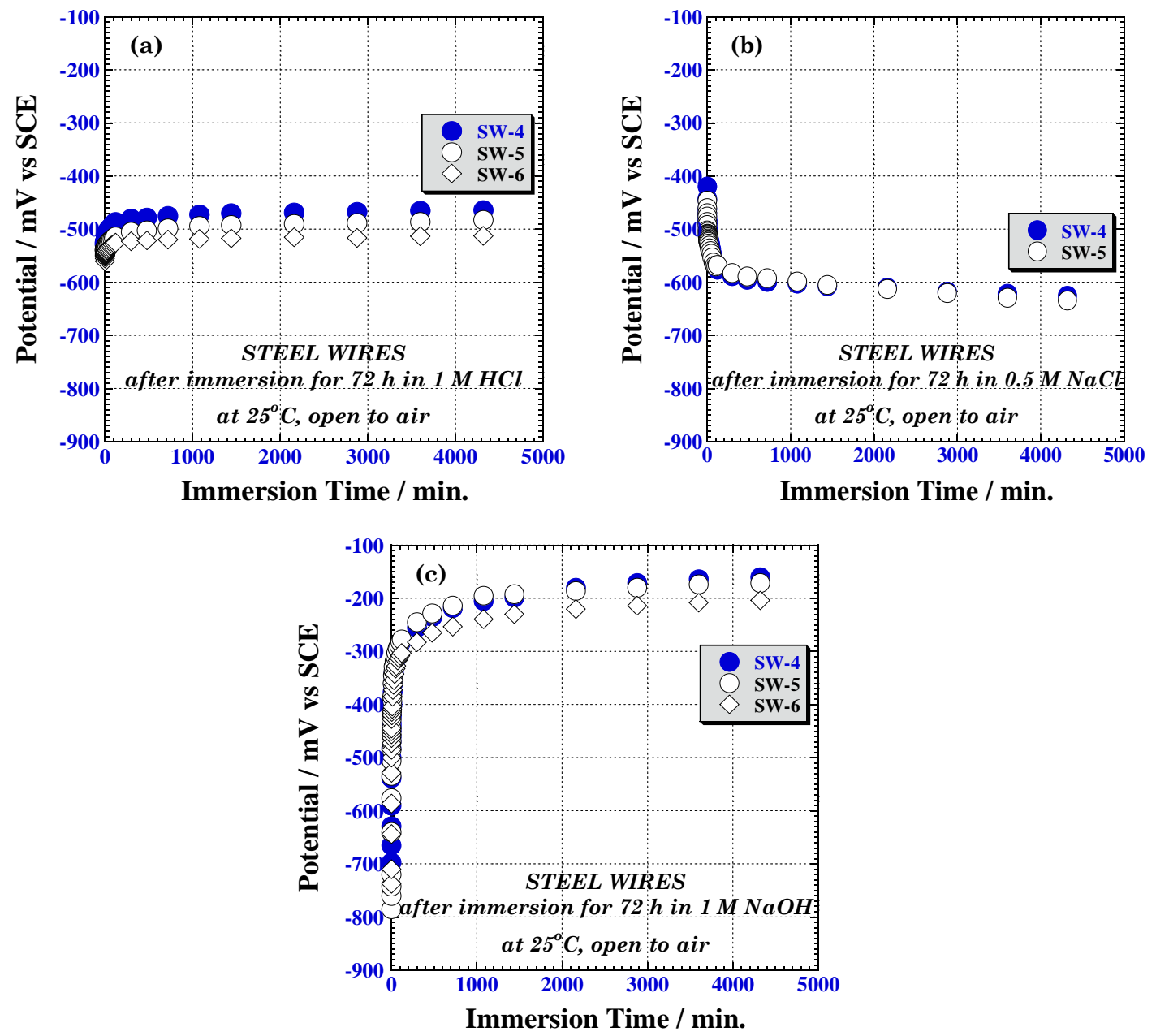

Figure 3: Changes in open circuit potentials for steel wires of Nepal in (a) $1 \mathrm{M} \mathrm{HCl}$, (b) $0.5 \mathrm{M} \mathrm{NaCl}$ and (c) $1 \mathrm{M} \mathrm{NaOH}$ solutions at $25^{\circ} \mathrm{C}$, open to air as a function of immersion time. 
The changes in the OCPs of the SW-4 and SW-5 are almost same and reach a stationary value of about $-630 \mathrm{mV}(\mathrm{SCE})$ after immersion for $72 \mathrm{~h}$ in $\mathrm{NaCl}$ solution at $25^{\circ} \mathrm{C}$. However, the nature of changes in the open circuit potentials for the carbon steel wires in alkaline $1 \mathrm{M}$ $\mathrm{NaOH}$ solution is not same as those in acidic $1 \mathrm{M} \mathrm{HCl}$ and neutral $0.5 \mathrm{M} \mathrm{NaCl}$ solutions. The ennoblement of open circuit potentials for the steel wires is clearly observed with immersion time in alkaline $1 \mathrm{M} \mathrm{NaOH}$ solution (Fig. 3.c). The open circuit potentials of the steel wires are initially about $-800 \mathrm{mV}$ (SCE) and they are shifted to about $-300 \mathrm{mV}$ (SCE) after immersion for about $2 \mathrm{~h}$, and finally the OCPs of the wires are in the range of about 205 to $-160 \mathrm{mV}$ (SCE) after immersion for 72 in $1 \mathrm{M} \mathrm{NaOH}$ solution. Consequently, all the examined carbon steel wires in the present study are more passive in alkaline $1 \mathrm{M} \mathrm{NaOH}$ than those in acidic $1 \mathrm{M} \mathrm{HCl}$ and neutral $0.5 \mathrm{M} \mathrm{NaCl}$ solutions.

Figure 4 shows the potentiostatic anodic and cathodic polarization curves for the steel wires after polarization for $1 \mathrm{~h}$ in alkaline $1 \mathrm{M} \mathrm{NaOH}$ solution at $25^{\circ} \mathrm{C}$, open to air. All the

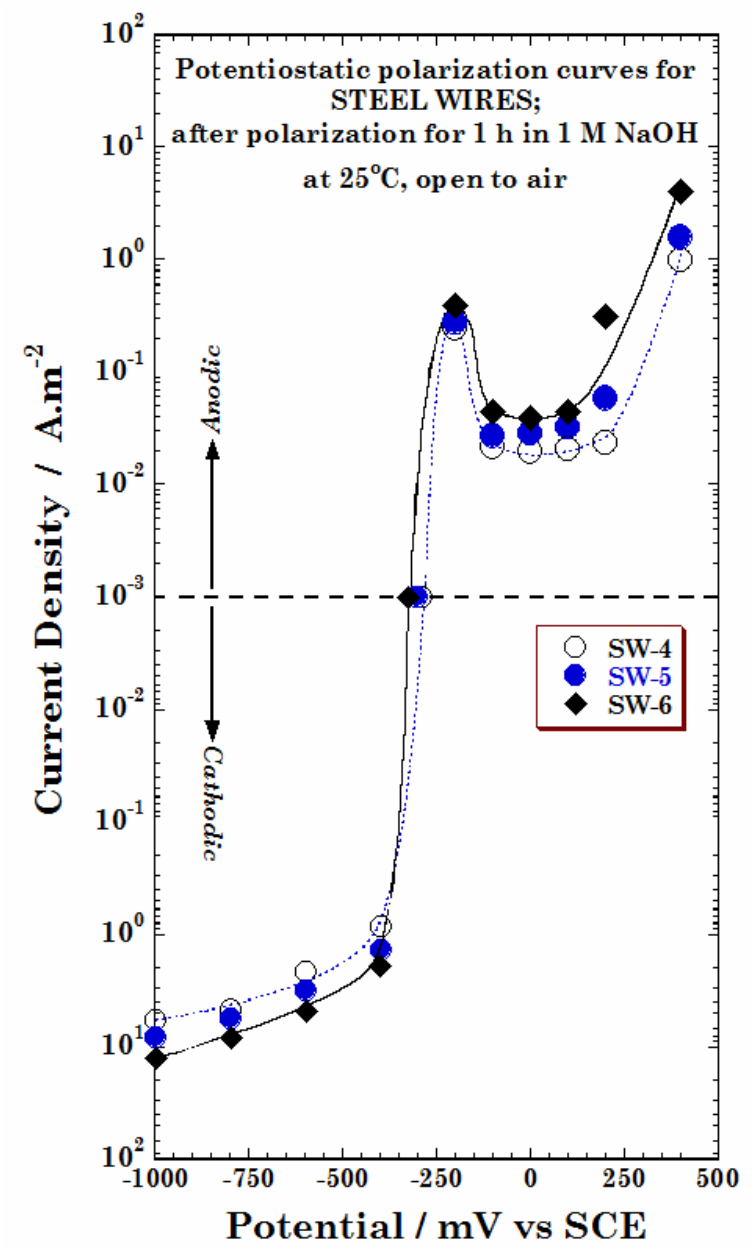

Figure 4: Potentiostatic polarization curves for steel wires of Nepal in $1 \mathrm{M} \mathrm{NaOH}$ solution at $25^{\circ} \mathrm{C}$, open to air. 
examined steel wires show clearly the active-passive transition and transpassivation. The steel wire is active at the potential range between -500 to $-200 \mathrm{mV}$ (SCE) while it is passive at the potential range between -200 to $250 \mathrm{mV}$ (SCE) in $1 \mathrm{M} \mathrm{NaOH}$ solution. The passive current density of the steel wires is in the range of 2-4 $x 10^{-2} \mathrm{~A} \cdot \mathrm{m}^{-2}$ in $1 \mathrm{M} \mathrm{NaOH}$ solution. Transpassivity is clearly seen after polarization at about $200 \mathrm{mV}$ (SCE) or more anodic potentials probably due to the formation of soluble ferrate $\left(\mathrm{FeO}_{4}{ }^{2-}\right)$ in $1 \mathrm{M} \mathrm{NaOH}$ solution. ${ }^{1}$ Consequently, the corrosion resistance of the steel wires produced in Nepal is significantly higher in $1 \mathrm{M} \mathrm{NaOH}$ than those in $1 \mathrm{M} \mathrm{HCl}$ and $0.5 \mathrm{M} \mathrm{NaCl}$ solutions as shown in Fig. 1 . This is mostly due to an ennoblement of the open circuit potentials of steel wires at passive potential regions in $1 \mathrm{M} \mathrm{NaOH}$ solution at $25^{\circ} \mathrm{C}$.

\section{Conclusions}

The passivation behavior of carbon steel wires produced in Nepal is studied in acidic 1 $\mathrm{M} \mathrm{HCl}$, neutral $0.5 \mathrm{M} \mathrm{NaCl}$ and alkaline $1 \mathrm{M} \mathrm{NaOH}$ solutions at $25^{\circ} \mathrm{C}$, open to air by immersion tests and electrochemical measurements. The following conclusions are drawn.

1. The steel wires produced by steel and iron companies 4 and 5 (SW-4 \& SW-5) showed higher corrosion resistance than that of the steel wire produced by the company 6 (SW-6) in all examined acidic, neutral and alkaline solutions.

2. All the examined carbon steel wires showed significantly higher corrosion resistance in $1 \mathrm{M} \mathrm{NaOH}$ solution than those in $1 \mathrm{M} \mathrm{HCl}$ and $0.5 \mathrm{M} \mathrm{NaCl}$ solutions at $25^{\circ} \mathrm{C}$, mostly due to an ennoblement of the open circuit potentials of steel wires at passive potential regions of steels in alkaline environments.

3. The faster dissolution of the steels of Nepal results in fast passivation by forming more protective passive films formed on the steel surface in alkaline $1 \mathrm{M} \mathrm{NaOH}$ solution. Therefore, the steel wires seem to be very corrosion resistance in very alkaline environments like of the reinforced concrete.

\section{Acknowledgements}

The author is very thankful to the Head of Central Department of Chemistry, Tribhuvan University, Kirtipur, Kathmandu, Nepal for providing the available research facilities to conduct this research work.

\section{References}

1. H. H. Uhlig and R. W. Revie, in Corrosion and Corrosion Control, $3^{\text {rd }}$ edition, 1991, p. 97.

2. S. L. Chawla and R. K. Gupta, Materials Selection for Corrosion Control. Materials Park, Ohio, ASM International, 1993.

3. Asami, K., Hashimoto, K. and Simodaira, S., Corros. Sci., 1978, 18, 151. 
4. T. Kamimura and M. Stratmann, Corros. Sci., 2001, 43, 429.

5. T. Shibata, Corros. Sci., 2007, 49, 20.

6. S. Fujimoto and H. Tsuchiya, Corros. Sci., 2007, 49, 195.

7. U. Kivisakk, Corros. Sci., 2003, 45, 485.

8. Y. Li, M. B. Ives, K.S. Coley and J. R. Rodda, Corros. Sci., 2004, 46, 1969.

9. Q. Qu, S. Jiang, L. Li, W. Bai, and J. Zhou, Corros. Sci., 2008, 50, 35.

10. I. Sekine, H. Ohkawa and T. Handa, Corros. Sci., 1982, 22, 1113.

11. F. Nagies, and K. E. Heusler, Electrochim. Acta, 1998, 43, 41.

12. D. D. N. Singh, R. Ghosh and B. K. Singh, Corros. Sci., 2002, 44, 1713.

13. J. A. Gonzalez, J. M. Miranda, E. Otero and S. Felius, Corros. Sci., 2007, 49, 436.

14. A. Nishikata, Y. Yamashita, H. Katayama, T. Tsuru, A. Usami, K. Tanabe and H. Mabuchi, Corros. Sci., 1995, 37, 2059.

15. R. E. Melchers, Corros. Sci., 2003, 45, 2609.

16. M. Reffass, R. Sabot, C. Savall, M. Jeannin, J. Creus and Ph. Refait, Corros. Sci., 2006, 48, 709.

17. H. S. Isaacs, Y. M. Looi and J. H. W. de Wit, Corros. Sci., 2007, 49, 53.

18. H. Ashassi-Sorkhabi and D. Seifzadeh, Intl. J. Elecrtochem. Sci., 2006, 1, 92.

19. V. R. Saliyan and A. V. Adhikari, Corros. Sci.., 2008, 50, 55.

20. B. An, X. Zhangi, E. Han and H. Li, J. Mater. Sci. Technol., 2004, 20(2), 220.

21. D. D. N. Singh, S. Yadav and J. K. Saha, Corros. Sci.., 2008, 50, 93.

22. J. Bhattarai, A. Kafle and N. P. Bhattarai, J. Nepal Chem. Soc., 2007, 22, 34.

23. J. Bhattarai, Nepal J. Sci. Technol., 2008, 9, 157. 